\title{
特集論交(㚆通行動分析の新展開) 交通行動分析の展開と課題
}

原田 昇*・森川高行 ${ }^{* *} \cdot$ 屋井鉄雄 ${ }^{* * *}$

\begin{abstract}
交通行動分析に大きな影響を与えた非集計分析手法が誔生して約20年が経過した. その間，交通行動分析では，アクティビティ分析やダイナミックなモデリングなど, より行動論に重点を置いた研究が発展する一方, 非集計離散型選択モデルとその周辺 分野の融合によって新しい展開を見せ始めている. 本論文は, 非集計分析手法に焦点 を当てながら, より広義の交通行動分析研究とその実用化の進展の動向, そして将来 の課題について整理を行なうものである.
\end{abstract}

Key Words : travel behavior analysis, dissaggregate travel demand model, review

\section{1.はじめに}

非集計分析などの交通行動分析は，既存手法に比べて より一般性の高い行動理論に基づく「より行動的なモデ ル」，既存手法では適用困難な分析課題を扱い得る「よ り実用的な分析手法」の, 一見, 矛盾する時代的要請に 応える分析手法として受け入れられてきたと言える. 効 用最大化理論に基づく非集計分析を交通計画手法として 受け入れるために, IIA制約の緩和などの理論的課題, サ ンプリングや集計手法などの実用化のための理論開発が 行なわれたのは周知の通りであり,これらの理論研究の 成果は, すでに，1984年の土木計画学講習会でその大半' が紹介されている. その後は, 新しい分析対象に非集計 分析を適用して新たな知見を得ようとする, いわゆる適 用研究が主流であり，実用化が大きく進んだ時期と言え る.しかし，この間に，一時点のトリップ単位のRevealed Preference（以下，R P ) データを用いる非集計分析に対 して, Stated Preference（以下, S P ) データ, パネルデー 夕など新しい夕イプのデータを活用する分析の開発や, 時空間プリズムやアクティビティ分析などの新しい分析 概念の提案，マーケティング分野などの分析技法を取り 入れた新たな交通分析手法の開発,さらには, 交通行動 の意思決定メカニズムに立ち戻り,より一般的な行動理 論のモデル化を目指す研究など, 交通行動分析の新展開 につながる研究成果も散見できる.また, 駐車規制, 経 路情報提供，需要管理型の交通政策の提案など，新しい 計画課題に応える「より実用的な」分析手法も必要とさ れている.

\footnotetext{
* 正会員 工博 東京大学助教授 工学部都市工学科

（テ113 東京都文京区本郷7-3-1）

** 正会員 Ph.D. 名古屋大学助教授 工学部土木工学科

*** 正会員 工博 東京工業大学助教授 工学部土木工学科
}

本特集は, このような現状を背景に, わが国の交通行 動分析が，この10年間の実用期を踏まえて新たな展開期 に移行しつつあるとの認識に基づき, 今後の交通行動研 究の発展に資することを目的として, 非集計分析を端緒 とする交通行動分析の軌跡と発展動向を整理するもので ある. 本論は, その総論として, 交通行動分析の様々な 研究のダイナミズムを整理し, 全体的な方向性と課題を 示す.この後を構成する 5 つの論文は,「より行動的で より実用的な」分析手法の開発に資するための新たな試 みである. 新しい研究テーマを理解頂くための工夫とし て, 各論文の前半に各テーマのレビューを行い, 後半に 最新の研究成果を示す構成としたため, 交通行動分析に 関する詳細な研究経緯はそちらを参照されたい.これら が新しい試みのすべてというわけではないが, 今後の展 開を示唆する意欲的な論文であることに間違いはない.

なお, 本特集は, 1991年の土木計画学研究発表会にお けるスペシャルセッション「交通の需要と行動の分析一 10 年の軌跡と将来」を基に発展させたものである．当日 の議論, 海外研究者からのコメントが本特集に寄与する ところは大きく，ここに感謝する次第である.なお，ス ペシャルセッションでは, 本特集では言及できなかった, 我が国における非集計分析の実用化状況, 動的分析とマー ケティング分析の事例などもまとめている．本特集とあ わせてご覧頂ければ幸いである.

\section{2. 交通行動分析研究の進展}

大規模な交通需要分析は，1950年代の半ばにアメリカ のシカゴ地域の交通計画を支援するために初めて行なわ れたことは周知のとおりである. その後10数年の交通需 要モデルは, 人の交通行動をマスとしてとらえ, 交通量 などの集計量を重力モデルやエントロピー・モデル代 表されるように物理学のアナロジーによってモデル化し 
たものが中心であった．このモデリングの考え方から， モデルの未知パラメータの推定に使われるデータやモデ ルから得られる予測值が, トラフィック・ゾーン単位で 集計された量であったので, 後には「集計モデル」と呼 ばれることになる．しかし，交通計画の目的の中心が， 公共交通機関の復権と理想的なモーダルシェアや，カー プーリングによる道路混雑解消などきめの細かいものに シフトしてくると，従来のマクロな予測モデルでは政策 分析に対応しににくくなってきた。このような背景の下 に，個人の行動原理を明示的に表し，集計したデータで はなく，個人レベルのデータを用いて推定を行なう「非 集計行動モデル」の開発が行なわれた.

ここで新たに導入された概念は，個人がある交通行動 を行なったときに得られる「効用」であり，1970年代の 前半にMcFadden ${ }^{1}$ によって, ランダム効用理論による離散 型選択モデルの理論的バックグラウンドと推定法が発表 され，交通需要分析や交通行動分析に大きな転機を迎え ることになった。このような歴史的背景から「非集計モ デル」という用語は，ロジットやプロビットに代表され るランダム効用理論に基づく離散型選択モデルを主に指 すようになった．また，集計モデルと此べた場合，非集 計モデルは，「行動」をより明示的に対象としているた め, 非集計行動モデル（Disaggregate Behavioral Model）と も呼ばれ，これが後に交通行動モデル＝（狭義の）非集 計モデルという一部の誤解を招くことにもなった．本論 文で言う「非集計分析」は，離散型選択モデルまたはそ の拡張モデルを用いた分析を指している.

いずれにしても，非集計モデルが交通行動分析にパラ ダイムシフトをもたらしたと称されるように，その劇的 デビューから早くも20年, 我が国に本格的に紹介されて からも10年以上が経過した，そして，いわゆる非集計モ デルの理論的展開や実用化のための研究は，1985年以前 に大方終了したとも言われており，近年では，周辺分野 の技術と結び付けた新たな発展や，交通行動のより本質 的な理解をもとにモデル化を目指す研究の発展などが目 立っている. 非集計モデルの研究が一段落した時点での レビューは原田 ${ }^{2}$ や $\mathrm{Yai}^{33}$ が詳細に行なっているため,ここ では非集計モデルの創成期からの研究上の発展を概観す るにとどめ, 近年の交通行動研究の動向をより詳しくレ ビューすることにする．また，本論文では交通行動研究 の方法論上の進展に焦点を当てたため, わが国の研究状 況がほとんど紹介されていないが，我が国における適用 状況などについては，文献 2)，3)や前述のスペシャルセッ ションのレビュー論文 ${ }^{4), 5)}$ を参照していただければ幸いで ある。

\section{(1) 非集計モデル研究の進展}

1970年代前半の劇的デビュー以来, 非集計離散型選択 モデルは，実務においても交通のいくつかの局面で従来
の集計モデルに取って替わると同時に，主にアメリカに おいてその計量経済学上の研究が多く行なわれた。非集 計行動モテルの最大の長所と言われた時間的・空間的移 転性の高さの検証と移転に伴うパラメータの更新法に関

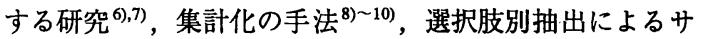
ンプルからの推定法 ${ }^{11,12)}$, 多数の選択肢を持つ場合の選択 肢のサンプリングによる推定法 ${ }^{13)}$ ， モデルの構造や特定化 （説明変数の選び方）に対する統計的検定の方法 ${ }^{14) ~ 16), ~}$ などがあげられ，これら一連の研究によって非集計離散 型選択モデルの理論的基䃈が確立された.

実務的には，モテルの推定が容易な多項ロジット

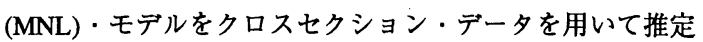
することが多かったが，適用の範囲を拡大していくうち に，この手法の限界が明らかになってきた。まず問題に なったのは, MNLモデルの暗默の仮定のうち，分析者が 意思決定者の選択肢集合を確定的に知っていること, ラ ンダム効用項の選択肢間の独立性，そしてこの仮定から 導かれるMNLモデルのIIA (Independence from Irrelevant Altematives)特性であった．このため，IIA特性を緩和した， より一般的な非集計離散型選択モデルの提案と適用に関 する研究が行なわれた.

Manski ${ }^{17)}$ は，多くの場合分析者にとって意思決定者の持 つ選択肢集合は不明瞭であることから確率的選択肢集合 を用いた 2 段階離散型選択モテルを提案した。これは, 通常の離散型選択モデルのより一般化されたモテルで, 1 段階目は選択肢の全体集合からある選択肢集合が意思 決定者の真の選択肢集合である確率を表し，2 段階目は その選択肢集合が与えられたうえである選択肢が選択さ れる確率を表している。この一般化モデルの特殊なもの

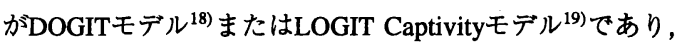
選択肢集合がただ一つの場合，すなわちその意思決定者 が非選択層（Captive）である場合を考虑している.

上記のように選択肢集合の不確実性を明示的にモデル 化することによってIIA特性を楥和する方向とは別に，効 用のランダム項の独立性の仮定を外すことによって NonIIAモデルを導くこともできる．代表的なものは，階層的 な選択構造を表したネスティッド・ロジット(NL)・モデ ル202,21) と，ランダム効用項が選択肢間で相関を持つ正規分 布を仮定した多項ブロビット(MNP)・モデル22)である．ま た，McFadden ${ }^{23)}$ は，MNLモデルとNLモデルをさらに一般 化したGEV (Generalized Extreme Value) モデルを提案した. NLモデルは推定が比較的容易であることから適用がかな り進んだが，MNPモデルは推定が困難なため実用の域に は達していない．MNPモデルのなかでも効用関数の係数 が確率変数であるRandom Taste Modellは最も一般化された 離散型選択モデルとして理論的には望ましく，現在その 実用的な推定法に関する研究が行われている24,25).

これらのNon-IIAモデルの開発は，行動仮説の一般化と 
それに基づくモデルの推定法の開発と言えよう.

一方では，行動とその説明要因の「測定」に関する研 究も行なわれてきた。もともと離散型選択分析が数理心 理学から発展してきたものであることから，心理学的手 法を用いてより精密に選択行動を表そうとする研究が初 期の頃から行なわれてきた ${ }^{26)}$. 心理学では，人間は外界か らの刺激を「知覚」し，その知覚值に基づいて行動意向 を持ち，行動に至るというプロセスを厳密に考えている. 交通行動を規定する要因についても旅行時間などの客観 的物理量をそのまま説明変数に用いるのではなく，何ら かの方法でその知覚值を得て，それを説明変数とする研 究である. また，選択の意思決定機構に関する研究も伝 統的に行われており，意思決定ルールが線形効用関数に 代表されるような通常の「補償型」（すべての属性間に 補償関係(trade-off)があるもの) でなく， $\mathrm{EBA}^{27}$ に代表さ れる「非補償型」のモデルも開発されている.

同様に心理学から発展してきたマーケティング・リサー チの手法を取り入れた方法として，S P データの利用の 研究 ${ }^{28}$ も盛んである．S P デー夕は一種の実験データであ ることから操作性が高く，実際の行動結果を表す R P デー 夕と補完的な性質を持っている。このような互いに補完 的な性質を持つ R P デー夕と S P デー夕を統合的に利用 して非集計モデルを推定する手法が提案されている ${ }^{29}$. 複 数データの利用は， R P , S P に限らずモデル移転性の 観点からも研究されており, 集計デー夕による非集計モ デルパラメータの更新法 ${ }^{30}$ などが発表された.

\section{(2) 交通活動分析と動的分析の台頭}

前節で述べたように, 非集計離散型選択モデルの理論 的研究とその一般化は主にアメリカにおいて行なわれた. これに対してイギリスとくにOxford大学の交通研究グルー プは，1970年代半ばから人間の活動と交通の関係を調べ る基礎的研究を行なってきた。つまり，交通は異なる地 点で行なう活動の「派生需要」であるから，交通行動の 理解のためにはまず時空間上で人間の活動を分析しなけ ればならないという主張である。このような立場を取る 手法をActivity-Based Approachと呼び，トリップに主眼を おいた分析法をTrip-Based Approachと名付けた。 このよう な議論は，1979年のオーストラリアで行なわれた国際交 通行動会議 (International Conference on Travel Behavior; ICTB）で始まり，1981年および1988年のOxford Conference でさらに活発な議論といくつかの研究成果が発表された.

(この経緯は，2つの Oxford Conference のProceedings ${ }^{31), 32)}$ に詳しく記されている．また，Pas ${ }^{33}$ は後者の中でこれま での交通需要モデル発展の経緯を簡略にまとめてい る. )

交通を活動との関連で捉えて,トリップのつながり （トリップ・チェイン）を分析する手法は，1960年代に 集計型の確率モデルで定式化されている ${ }^{34)}$.また, Adler

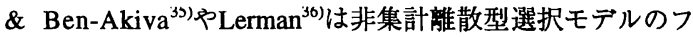
レームワークでトリップ・チェインを分析した. その後, Activity-Based Approachは, 1 日単位から複数日単位の活 動・交通関連分析, 時空間制約の考虑, 交通と活動の事 前スケジューリングの分析などに発展している ${ }^{37 ~ 40) . ~}$

このようなトリップ間の結び付きを重視するフレーム ワークでトリップを分析する場合, 当該トリップの前後 のトリップや活動が大きく影響するため，モデリングの 手法としてはダイナミックなものとなる，ただし，その 影䇒範囲が長くて 1 日から数日であるため, ここでは短 期のダイナミックなモデルと呼ふこことにする。これに対 して，数か月から 10 数年のライフサイクルや社会情勢の 変化に関連して交通行動がどう変化していくかを分析す る交通の長期的ダイナミズムに関する研究が，1980年代 の後半から盛んになっている ${ }^{41) ~ 43)}$. 交通の長期的ダイナ ミズムの例としては, 自家用車の保有が世帯のライフサ イクルによってどう变化するか, 新しい交通機関の導入 によって交通機関の選択がどうシフトしていくか，など があげられる．長期的ダイナミズムを考㦄しなくてはな らない根拠は，1時点のクロスセクション・データに基 づく静的分析が，1)行動原理が定常的である，2)常に均衡 状態にある，3)行動の変化は瞬時に変わりまた可逆的であ る，という強い仮定に基づいていることである．また， 静的モデルに取り入れていない交通行動の要因に，ライ フスタイル，個人の喍好などクロスセクション・データ では扱いにくいものが多いことも動的分析のきっかけと なった. 交通の長期的ダイナミズムの分析には, 通常複 数時点のデー夕（縦断テータ）を用いるが，とくに同じ サンブルに対して複数時点において調査したものをパネ ル・データと呼び，このような分析には極めて有効であ る. パネル分析は, 多くの適用研究と共に, 誤差項の系 列相関などを考慮した計量経済学的研究の発展ももたら した ${ }^{44)}$.

\section{(3) 交通行動研究の最新動向}

以上述べてきたように, 欧米における交通需要モデル に関する研究は, 物理学のアナロジーによる現象の説明 から、より交通行動論に力点をおいたものに移り変わっ てきている：一方 1980年代以降の交通行動分析に関する 研究は，まったく停滞期に入ってしまったとの見方も存 在する.Hartgen ${ }^{45}$ によると，1987年のフランスにおける ICTBで，ある著名なアメリカの交通研究者が「ここ10年 ・間に交通行動に関する新しいアイデアは一つもない」と 発表したという．象徵的なことは，欧米における交通分 析に関する研究予算の劇的減少である：例えば，アメリ 力運輸省の大学に対する1988年の交通研究の補助金額は,

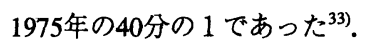

このように，パラダイムシフトをもたらすような方法 論上の発展は近年見られないが，1980年代後半からモー 


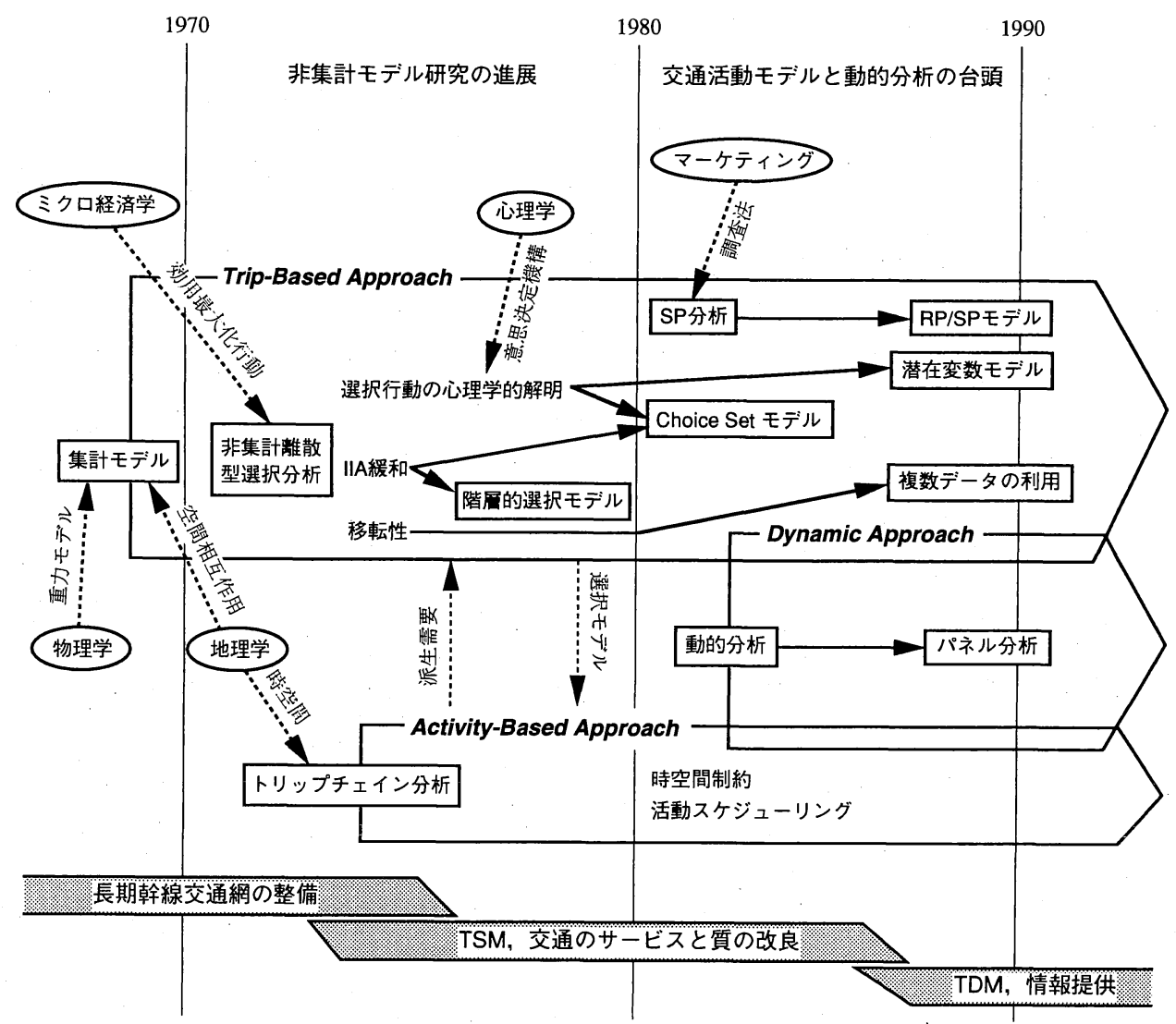

図-1 交通行動研究の変遷

タリゼーションの進展に関する研究が世界中で社会的に 認知され, 交通行動研究の大きな研究テーマとして現在 最も活発に研究がなされている.モータリゼーションの 進展がもたらす社会問題には, 混雑問題, 環境問題，工 ネルギー問題, 都心部の衰退問題などが含まれる.

まず，自家用車の複数保有の進展とその使用量の分析 は，世帯のライフ・スタイルと社会環境の变化に基づい た長期的ダイナミズムを持つものであるから，パネル． データを用いたダイナミックなモデルと離散連続型モデ

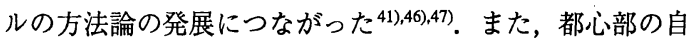
動車の飽和による都市機能の麻痖を回避するための駐車 対策，ロード：プライシングなどの政策の効果分析のた

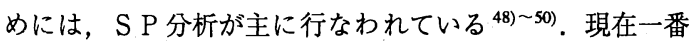
活発に研究が行なわれている分野は, IVHS(Inteligent Vehicle Highway System)研究に代表されるような，ドライ バーに対する情報提供とそれに対するドライバーの行動 分析であり，ここでもS Pデー夕を使った分析が多く行 なわれている ${ }^{51) \sim 53)}$. 毎日与えられる情報に対してドライ バーがどのように経路や出発時刻を変えていくかという
日単位のダイナミズムを分析するための基礎的研究も進 んでいる ${ }^{54), 55)}$. その他, 通信技術の発達とそれが交通に与 える影響 ${ }^{56)}$, 化石燃料に対する代替燃料 ${ }^{57)}$, 環境問題に対 応するための政策（例えば二酸化炭素排出税）とそれに

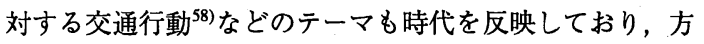
法論的には S P データの利用が多い.

一方, 上記の研究と連携する方法論的な研究としては,

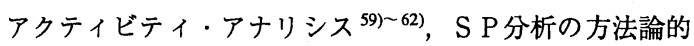

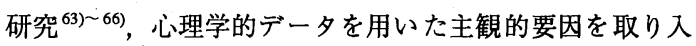

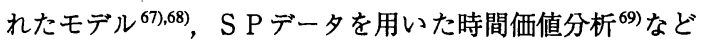
が現在も盛んに行なわれている分野である.

\section{(4) 交通行動研究の変顠}

これまでに述べてきた交通行動研究の変遷を簡潔に表 したものが図一 1 である. 図中で, 四角で囲まれたキー ワードはその時代に誕生した主な分析法やモデルを表し, 実線の矢印でその流れを示した. ただし，その分析法や モデルがその時代で研究が終了したという意味ではなく， 現在も若干姿を変えながら研究の大きな流れとして継続 している様子を 3 つの大きなアプローチ（Trip-Based, 
Dynamic, Activity-Based）を示す矢印として表した．棈円 で囲まれた学問分野と破線の矢印上のキーワードは，交 通行動研究の主な分析法にどのような影響を与えたかを 表した.また，図の一番下に交通計画の実務上の要請を 極めて大きくキーワードとして捉えたものを示した.

このように交通行動研究は時代の要請とともに, 様々 な学問領域や異なるアプローチ間で影響を及ほし合いな がら, 典型的な学際領域として進展してきたのである.

\section{3. 交通行動研究の課題と本特集の位置付け}

\section{(1) 交通行動研究の今後の課題}

1980年代にActivity-Based Approachが台頭してきた頃に， それまで主にTrip-Basedに適用されてきた非集計離散型選 択モデルは交通行動モデルとは程遠いものだ，との議論 が沸き起こった。これは，1980年以降あまりに安易に非 集計離散型選択のTrip-Based Modelを適用してきたことに 対する敕鐘であったとも言えよう．ところが，10数年たっ た現在もActivity-Based Approachによる有用な実務的成果 は非常に限られている。これには，Activity-Based Approachのための強力な方法論がないこと年が最も大きな 理由であろう. Activity-Based Approachのこれまでの定量 的交通行動分析に対する貢献は, Trip-Based Modelの説明 変数に活動要因を取り入れたことなどが挙げられている. しかし, Activity-Based Approachは, 依然交通と活動の関 係の理解の過程にとどまっている研究が多く,どのよう な交通の局面で有用かの整理と実用的な方法論の開発が 必要であろう.

ダイナミックな分析の方法論は, 今後必要性を増すで あろう. 自動車保有と使用量, 通信技術の発展と交通行 動, エネルギー問題, 環境問題など長期的な交通戦略を 支援するためには時系列データが不可欠であろう。また， 予測の事後評価が欠けている場合が多いが，事前・事後 データによる予測值と予測手法の評価, 交通状況の変化 に対する利用者の学習過程の解明など, 時系列データの 利用によって実務的・学問的に興味深いものは多い.ま た，パホル調查は非常に有用なデータを与えるが，すべ ての調査時点で標本が母集団を正しく表すかどうかやモ デル推定に関する計量経済学的課題も多く残されている.

S P 分析は, ロード・プライシングや情報提供システ ムなど革新的な交通政策の出現によって最近特に注目を 集めているが，その調查法の柔軟性・操作性の高さから 今後も様々な政策評価のために利用が増えると思われる. この分野にも研究課題が多く, 調查法自体の改善, SP データの信頼性の評価，モデルの推定法などが主なテー マと思われる.

ここで，交通需要と交通行動の分析に考慮しなくては ならない事項を以下に簡単に整理した.

a) 適用対象
どのような外的条件の変化を対象として交通行動の変 化を予測するかがまず重要である。これには，PT調查に 基づく都市圈総合交通計画のように人口や経済指標の伸 び，大規模開発計画や広域幹線交通施設の整備に基づい た将来交通量予測といった包括的なものから，ある交通 機関の快適性を改善した場合の利用者数の予測といった 局部的なものまであろう．近年，国内外で注目を集めて いる交通政策は，ロード・プライシングや駐車規制など の需要管理型政策や，ドライバーへの情報提供などであ り，これらの政策に対する自動車交通発生量や経路選択, 出発時間選択の予測に関する研究が行なわれている. 通 信技術の進歩が交通に与える影響，交通と自然環境，工 ネルギー問題，交通事故のリスクと交通行動なども緊急 のテーマとしてあげられている.

\section{b) 分析範囲}

同じ適用対象でも，どの範囲の交通の局面まで分析を 行なうかが異なる場合がある．ある交通機関に対するイ ンパクトを分析する際にも，居住地や就業地の選択から 分析するか，交通の発生から捉えるか，分布から捉える か, 機関選択や経路選択のみを捉えるかによって分析の フレームワークは異なる．また，交通を活動からの派生 需要であることを明示的に考えたActivity-Based Approach を採用するか, トリップ・チエインを考虑するか, 単独 のトリッブを対象にするかによってもフレームワークは 異なる．さらに，交通施設のパフォーマンスによる供給 サイドとの均衡を明示的に考虑する場合もある.

c) 意思決定構造

分析の対象となる交通行動を規定する意思決定構造を どのように捉えるかは，モデリングの大前提になるもの である．行動のダイナミズムは考虑すべきか，個人の行 動は他の人，とくに同一世帯内の人と独立か, 選択肢集 合はどう捉えるのか, 通常の補償型効用関数モデルは妥 当であるか, 意思決定の説明要因は客観值で良いのか知 覚值を用いるべきか, S P 調査に対する回答は実際の行 動と同じ意思決定構造を持つのか, 意思決定構造の解明 のための諸手法（例えば線形構造方程式型因果パス分析 手法）の適用性，などのテーマが考えられる.

d) 調査法

適用対象, 分析範囲, 仮定した意思決定構造に適した データとその調査法に関する研究がある. 自動車保有な どの長期的なダイナミズムを考虑した方がよい対象には パネル調查が必要であろうし, 日単位の変動を分析する 際には複数日のトラベル・ダイアリー調査が適当である. また，現存しない交通サービスのインパクト分析には S P 調查が有効な場合が多い．SP調査法に関する研究は近 年盛んであり，実験計画法に基づいた選択肢の設定や携 帯用コンピュータによるインタビュー調査などが行なわ れている. 
e) モデルの推定論

意思決定構造とそれを解明するためのデータが与えら れたとき，モデルの未知パラメータをいかに推定すべき かという計量経済学的テーマには, 多くの研究の蓄積が あるが, 新しい行動仮説とデータ収集法の出現によって 課題は多く残されている。例えば，パネル・データから の離散型または離散連続型モデルの推定, 様々な種類の S P データからの推定, 心理学的主観的データの利用, 複数データ・ソースの利用，などである．また，古典的 な問題でありながら未だに実用的な手法が見つからない ものとして，MNPモデルの推定や選択肢の数が非常に多 いときの離散型選択モデルの推定があげられる.

f) 予測法

推定された（ほとんどの場合非集計レベルの）モデル を用いて，どのような予測值を計画の意思決定者に提供 するか, またその予測値の信頼性はどの程度かの分析も 必要である、さらに，予測の事後分析も重要である。ま た, 計画案の更新を含めた計画立案プロセスと予測プロ セスの整合性も課題となろう.

\section{(2) 本特集の位置付け}

ここで，本レビュー論文とともに本特集を構成する 5 つの研究論文を, 上記の課題の整理項目と関連付けなが ら, その交通行動研究上の位置付けを簡単に示す. 表一 1 は, それぞれの論文が整理項目a) f)のどの項目に最も 力点を置き（表中@印）, どの点についても貢献が見ら れるか（表中○印）を表したものである.

まず，西井による「時空間制約下における 2 ストップ チエインのパス選択モデル」では, 本レビュー論文で詳 しく触れられなかったトリップチェイン研究の発展経緯 を補完的に述べるとともに，アクティビティ・アプロー チに基づく交通のより根源的な解釈から，交通行動にお ける時空間の制約を取り入れて分析している.この論文 は，項目b)とc)に力点を置いていると言える.

森川・佐々木による「主観的要因を考虑した非集計離 散型選択モデル」は，2.で述べた「測定」の問題と離散型 選択モデルの一般化を狙ったものである.ここでは伝統 的な行動結果のデータだけでなく, 主観的なデータも統 合的に利用して交通行動者の意思決定機構をより心理学 的に分析しょうと試みている.この論文は，c)が中心であ るがe)についても新たな提案を行っている.

屋井・森地による「複数データの統合による交通需要 モデルの推定技法」は, 複数のデータの統合によってモ デルの精緻化を試みる点では前論文と同様な視点を持っ ているが，本論文では非集計データで推定したパラメー 夕を集計レベルのシェアデータでベイズ更新するという， より実用的な方法を提案している，これは，e)が中心であ るが，d)にも当然関連しているものである.

リダサン・田村・石田・黑川の「開発途上国における
表-1 各論論文の位置付け

\begin{tabular}{|c|c|c|c|c|c|c|}
\hline 著者名 & $\begin{array}{c}\text { a) } \\
\text { 適用 } \\
\text { 対象 }\end{array}$ & $\begin{array}{l}\text { b) } \\
\text { 分析 } \\
\text { 範囲 }\end{array}$ & $\begin{array}{c}\text { c) } \\
\text { 意思決 } \\
\text { 定構造 }\end{array}$ & $\begin{array}{c}\text { d) } \\
\text { 調査法 }\end{array}$ & $\begin{array}{c}\text { e) } \\
\text { モデルの } \\
\text { 推定論 }\end{array}$ & $\begin{array}{c}\text { f) } \\
\text { 予測法 }\end{array}$ \\
\hline 西井 & & (0) & & & & \\
\hline 森川·佐々木 & & & (a) & & 0 & \\
\hline 屋井·森地 & & & & & (a) & \\
\hline $\begin{array}{l}\text { リダサン・田村 } \\
\text { 石田・黑川 }\end{array}$ & 0 & & & (a) & & \\
\hline 室町 · 兵藤 · 原田 & (0) & & 0 & & & \\
\hline
\end{tabular}

交通行動のパネル分析」では, 近年先進国において実用 化が進んできた交通パネル調査を, 調査環境の良くない 発展途上国において実施し, 調査方法の検討と発展途上 国における交通行動の急激な変化を分析している．これ は，新たな調査法と発展途上国という意味で，d)とa)に関 するものである.

最後に, 室町・兵藤・原田による「情報提供による駐 車場選択行動変化のモデル分析」は, 最近交通行動研究 で最も話題の多い「ドライバーに対する情報提供」とい うテーマの中でも比較的取り扱いやすい駐車場選択行動 を対象にして分析したものである．ここでは，情報の精 度に焦点を当ててそれが選択行動に与える影锌を検討し ている，これは，a)に力点を置きながら，c)についても考 察を行うている.

\section{4. おわりに}

狭義の非集計モデルすなわちランダム効用理論に基づ く離散型選択モデルは，交通行動研究と実用に2つの大 きな役割を果たしたと思われる，ひとつは，その導出過 程において, 合理的選択, ランダム効用, 選択肢集合, など数多くの有用な概念を発案または社会科学の分野か ら移入してきたことである。これは離散型選択モデルの 利用いかんに関わらず, 現在の交通行動分析には欠かせ ない概念である．もうひとつは，実用面としてロジット モデルのような非常に簡単かつ有用な分析道具を提供し たことである. 実務家の間では様々な需要予測にパッケー ジ化されたロジットモデルを利用しているし，より広範 な交通行動分析を行なっている研究者も行動のいろいろ な局面でロジットモデルを道具として利用することは多 w.

このように非集計分析は, 交通行動の科学的分析に多 大な貢献をしたことは確かである.しかし, 原単位法, 現在パターン法, トレンド法, 重力モデルなどの伝統的 な交通需要分析手法の多くを非集計モデルが取って代わ ることは過大な期待であろうし, それに研究の重点を置 き過ざることは労力の無駄にもなりかねない. 交通計画, 
とくに需要面の重要な課題は, IVHSに代表される様な情 報化やテクノロジーの進歩による新たな交通サービス， 成熟した社会としての都市の交通需要管理（TDM）, 沿 道土地利用などと交通との関係を改善するための交通イ ンパクト・アセスメント，高齢化社会でのモビリティと 安全性の確保, 環境・エネルギー問題，新たな物流シス テムへの挑戦，などかつてよりも断然にきめの細かい政 策分析を必要とする方向に向かっている．この辺りに今 後の交通行動研究の方向が見いだせるのではないであろ うか. そして新たな研究成果が，計画現場で活かされる よう努力しなければならないことは言うまでもないであ ろう。

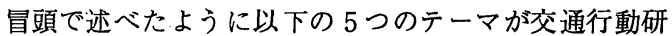
究の新しい動向を網羅しているわけでは決してないが, それぞれに新しい分野に意欲的に取り組んでいる．本レ ビュー論文とあわせて，交通研究者や実務家に参考とな り刺激となれば幸いである.

\section{考文 献}

1) McFadden, D.: Conditional Logit Analysis of Qualitative Choice Behavior, In Frontiers in Econometrics, P. Zarembka, ed., Academic Press, New York, pp.105-142, 1974.

2) 原田 昇：非集計行動モデルによる多次元選択行動の分析, 土木計画学研究·論文集, No.4, pp.15-28, 1986.

3) Yai, T.: Disaggregate Behavioural Models and Their Applications in Japan, Trnsp. Res., Vol.23A, No.1, pp.45-52, 1989.

4) 屋井鉄雄・森川高行 : 交通需要モデル研究のダイナミズムー 10年の軌跡, 土木計画学研究・講演集, No.14(2), pp.1-8, 1991.

5）原田 昇・兵藤哲朗：交通行動分析のフロンティアー混乱と 仕切り, 土木計画学研究・講演集, No.14(2), pp.9-16, 1991.

6) Atherton, T. \& Ben-Akiva, M.: Transferability and Updating of Disaggregate Travel Demand Models, Trnsp. Res. Rec. 610, pp.12$18,1976$.

7) Koppelman, F. \& Wilmot, C.: Transferability Analysis of Disaggregate Choice Models, Trnsp. Res. Rec. 895, 1982.

8) Talvitie, A.: Aggregate Travel Demand Analysis with Disaggregate or Aggregate Travel Demand Models, Proc. of Trnsp. Res. Forum, 14, pp.583-603, 1973.

9) McFadden, D. \& Reid, F.: Aggregate Travel Demand Forecasting from Disaggregated Behavioral Models, Trnsp. Res. Rec. 534, pp.24-37, 1975.

10) Reid, F.: Minimizing Error in Aggregate Predictions from Disaggregate Models, Trnsp. Res. Rec. 673, pp.59-65, 1978.

11) Manski, C. \& Lerman, S.: The Estimation of Choice Probabilities from Choice-Based Samples, Econometrica 45, pp.1977-1988, 1977.

12) Lerman, S. \& Manski, C.: Sample Design for Discrete Choice Analysis of Travel Behavior: The State of the Art, Trnsp. Res., Vol.13A, pp.29-44, 1979.

13) McFadden, D.: Modelling the Choice of Residential Location, In Spatial Interaction Theory and Planning Models, A. Karlqvist, L. Lundqvist, F. Snickars and J.W. Weibull, eds., North-Holland, pp.75-96, 1978 .

14) McFadden, D., Tye, W. \& Train, K.: An Application of Diagnostic Tests for the Irrelevant Alternatives Property of the Multinomial
Logit Model, Tmsp. Res. Rec. 637, pp.39-46, 1977.

15) Horowitz, J.: Specification Tests for Probabilistic Choice Models, Trnsp. Res., Vol:16A, pp.383-394, 1982.

16) Horowitz, J.: Testing Probabilistic Discrete Choice Models of Travel Demand by Comparing Predicted and Observed Aggregate Choice Shares, Trnsp. Res., Vol.19B, pp.17-38, 1985.

17) Manski, C.: The Structure of Random Utility Models, Theory and Decision 8, pp.229-254, 1977.

18) Gaudry, M. \& Dagenais, M.: The Dogit Model, Trnsp. Res., Vol.13B, pp.105-111, 1979.

19) Swait, J. \& Ben-Akiva, M.: Incorporating Random Constraints in Discrete Models of Choice Set Generation, Trnsp. Res., Vol.21B, pp.91-102, 1987.

20) Ben-Akiva, M.: Structure of Passenger Travel Demand Models, Trnsp. Res. Rec. 526, pp.26-42, 1974.

21) Ben-Akiva, M. \& Lerman, S.: Disaggregate Travel and Mobility Choice Models and Measures of Accessibility, In Behavioral Travel Modelling, D. Hensher and P. Stopher, eds., Croom Helm, London, 1979.

22) Daganzo, C: Multinomial Probit, Academic Press, New York, 1979.

23) McFadden, D.: Econometric Models of Probabilistic Choice, In Structural Analysis of Discrete Data, C. Manski and D. McFadden, eds., MIT Press, Cambridge, U.S.A., pp.198-272, 1981.

24) Bunch, D.S.: A Comparison of Algorithms for Maximum Likelihood Estimation of Finite Mixture Distribution Models, Jour. of Econometrics, Vol.38, No.1/2, pp.145-167, 1989.

25) McFadden, D.: A Method of Simulated Moments for Estimation of the Multinomial Probit without Numerical Integration, Econometrica, 57, 1989.

26) Recker, W.W. \& Golob, T.F.: An Attitudinal Modal Choice Model, Trnsp. Res., Vol.10B, pp.299-310, 1976.

27) Tversky, A.: Elimination by Aspects: A Theory of Choice, Psychological Review, Vol.79, No.4, pp.281-299, 1972.

28) Stated Preference Methods in Transport Research (Special Issue), Jour. of Transport Economics and Policy, Vol.XXII, No.1, 1988.

29) Ben-Akiva, M. \& Morikawa, T.: Estimation of Travel Demand Models from Multiple Data Sources, In Transportation and Traffic Theory, M. Koshi, ed., Elsevier, New York, pp.461-476, 1990.

30) Yai, T., Morichi, S. \& Fan, K.: Disaggregate Modelling by MultiSource Data, Proc. of WCTR, Vol.IV, pp.249-262, 1989.

31) Carpenter, S. \& Jones, P.M. (eds.): Recent Advances in Travel Demand Analysis, Gower, England, 1983.

32) Jones, P.M. (ed.): Developments in Dynamic and Activity-Based Approaches to Travel Analysis, Avebury, England, 1990.

33) Pas, E.: Is Travel Demand Analysis and Modelling in the Doldrums?, In Developments in Dynamic and Activity-Based Approaches to Travel Analysis, P. Jones, ed., Avebury, England, 1990.

34) Horton, F.E. \& Wagner, W.E.: A Markovian Analysis of Urban Travel Behaviour, Highway Research Rec., No.165, 1967.

35) Adler, R. \& Ben-Akiva, M.: A Theoretical and Empirical Model of Trip Chaining Behaviour, Trnsp. Res., Vol.13B, pp.243-257, 1979.

36) Lerman, S.: The Use of Disaggregate Choice Models in SemiMarkov Process Models of Trip Chaining Behaviour, Trnsp. Sci., Vol.13, No.4, 1979.

37) Pas, E. \& Koppelman, F.: An Examination of the Determinants of Day-to-Day Variability in Individuals' Urban Travel Behavior, Transportation, 13, pp.183-200, 1986.

38) Hanson, S. \& Huff, J.O.: Systematic Variability in Repetitious Travel, Transportation, 15, pp.111-135, 1988. 
39) Kitamura, R.: An Analysis of Weekly Activity Patterns and Travel Expenditure, In Behavioral Modeling Approaches in Geography and Planning, R.G. Gollege and H.J.P. Timmermans, eds., Croom Helm, London, pp.399-423, 1988.

40) Pas, E.: Weekly Travel-Activity Behavior, Transportation, 15, pp.89-109, 1988.

41) Kitamura, R.: Panel Analysis in Transportation Planning: An Overview, Trnsp. Res., Vol.24A, pp.401-415, 1990.

42) Meurs, H.: Dynamic Analysis of Trip Generation, Trnsp. Res., Vol.24A, pp.427-442, 1990.

43) Hensher, D.A. \& Smith, N.C.: Estimating Automobile Utilization with Panel Data: An Investigation of Alternative Assumptions of Initial Conditions and Error Covariances, Trnsp. Res., Vol.24A, pp.417-426, 1990.

44) Kitamura, R. \& Bunch, D.S.: Heterogeneity and Stated Dependence in Household Car Owvership: A Panel Analysis Using Ordered Response Probit Models with Error Components, In Transportation and Traffic Theory, M. Koshi, ed., Elsevier, New York, pp.477-498, 1990.

45) Hartgen, D.T.: Policy Opportunities for Travel Behaviour Analysis, Presented at the 5th International Conference on Travel Behaviour, Aix-en-Provence, France, 1987.

46) Kitamura, R.: A Panel Analysis of Household Car Ownership and Mobility, Proc. of JSCE, No.383, pp.13-27, 1987.

47) Golob, T.: The Dynamics of Household Travel Time Expenditures and Car Ownership Decisions, Trnsp. Res., Vol.24A, pp.443-463, 1990.

48) Harrison, W.J., Pell, C., Jones, P.M. \& Ashton, H.: Some Advances in Model Design Developed for the Practical Assessment of Road Pricing in Hong Kong, Trnsp. Res., Vol.20A, pp.135-143, 1986.

49) Polak, J. \& Jones, P.: Assessing Traveller Responses to Road Pricing Options, Preprints of 6th ICTB, Vol.1, Quebec, pp.66-82, 1991.

50) Vythoulkas, P.: Evaluating the Effects of Road Pricing during the Morning Peak, Preprints of 6th ICTB, Vol.1, Quebec, pp.297-313, 1991.

51) Bonsall, P. \& Parry, T.: Using an Interactive Route-Choice Simulator to Investigate Drivers' Compliance with Route Guidance Advice, Preprints of 6th ICTB, Vol.2, Quebec, pp.329-345, 1991.

52) Van der Mede, P. \& Van Berkum, E.: BEAST - A Behavioral Approach to Simulating Travellers, Preprints of 6th ICTB, Vol.1, Quebec, pp.283-296, 1991.

53) Khattak, A., Schofer, J. \& Koppelman, F.: Commuters' Enroute Diversion and Return Decisions: IVHS Design Implications, Preprints of 6th ICTB, Vol.2, Quebec, pp.363-376, 1991.

54) de Palma, A., Ben-Akiva, M. \& Litinas, N.: Stochastic Equilibrium Model of Peak-Period Traffic Congestion, Trnsp. Sci., Vol.17, pp.430-453, 1983.
55) Mahmassani, H.S.: Dynamic Models of Commuter Behavior: Experimental Investigation and Application to the Analysis of Planned Traffic Disruptions, Trnsp. Res., Vol.24A, pp.465-484, 1990.

56) Telecommunications and Travel Interactions (Special Issue), Trnsp. Res., Vol.22A, No.4, 1988.

57) Alternative Fuels (Special Issue), Trnsp. Res., Vol.23A, No.3, 1989.

58) Bradley, M. \& Gunn, H.: A Stated Preference Analysis of Values of Travel Time in the Netherlands, Tmsp. Res. Rec., 1990.

59) Pas, E.: Analytically Derived Classifications of Daily TravelActivity Behavior: Description, Evaluation and Interpretation, Trnsp. Res. Rec. 879, pp.9-15, 1982.

60) Jones, P.M., Dix, M.C., Clarke, M.I. \& Heggie, I.: Understanding Travel Behaviour, Gower, England, 1983.

61) Huff, J. \& Hanson, S.: Measurement of Habitual Behavior: Examining Systematic Variability in Repetitive Travel, In Developments in Dynamic and Activity-Based Approaches to Travel Analysis, P. Jones, ed., Avebury, pp.229-249, 1990.

62) Kitamura, R., Nishii, K. \& Goulias, K.: Trip Chaining Behavior by Central City Commuter: A Causal Analysis of Time-Space Constraints, In Developments in Dynamic and Activity Based Approaches to Travel Analysis, P. Jones, ed., Avebury, pp.145-170, 1990.

63) Bradley, M., Grosvenor, T. \& Bouma, A.: An Application of Computer-Based Stated Preference to Study Mode Switching in the Netherlands, PTRC 18th Annual Summer Meeting, Proc. of Seminar D, Univ. of Sussex, 1988.

64) Louviere, J.J.: Conjoint Analysis Modelling of Stated Preference, Jour. of Transport Economic and Policy, Vol.22, No.1, pp.93-118, 1988.

65) Bates, J.: Econometric Issues in Stated Preference Analysis, Jour. of Transport Economic and Policy, Vol.22, No.1, pp.59-69, 1988.

66) Ben-Akiva, M., Morikawa, T. \& Shiroishi, F.: Analysis of the Reliability of Preference Ranking Data, Jour. of Business Res., Vol.24, No.2, pp.149-164, 1992.

67) Golob, T., Horowitz, A. \& Wachs, M.: Attitude-Behaviour Relationships in Travel Demand Modelling, Behavioural Travel Modelling, pp.739-757, 1979.

68) Koppelman, F. \& Lyon, P.: Attitudinal Analysis of Work/School Travel, Trnsp. Sci., Vol.15, pp.233-254, 1981.

69) Bonsall, P.: Transfer Price Data - Its Definition, Collection and Use, In New Survey Methods in Transport, E.S. Ampt, A.J. Richardson and W. Brog, eds., VNU Press, 1985.

70) Kitamura, R.: An Evaluation of Activity-Based Travel Analysis, Transportation, 15, pp.9-34, 1988.

(1993. 2.5 受付)

\section{REVIEW AND PERSPECTIVE OF TRAVEL BEHAVIOR ANALYSIS FOCUSING ON DISAGGREGATE TRAVEL DEMAND MODELS}

Noboru HARATA, Takayuki MORIKAWA and Tetsuo YAI

Travel behavior analysis attained a new age with the emergence of the disaggregate travel demand modeling techniques about 20 years ago. Since then it has been developing the behavior-rich approaches such as activity-based modeling and dynamic modeling. The disaggregate modeling methodology has also been evolving itself by incorporating techniques developed in psychometrics and marketing science. The paper reviews the evolving history of travel behavior analysis focusing on disaggregate demand models, and discusses on future research problems and practical requirement of the analysis. 